Т.Ю. Кравченко (Москва, Россия)

Раиса Романовна Кузнецова

T.Yu. Kravchenko (Moscow, Russia)

\title{
Raisa Romanovna Kuznetsova
}

Когда-то на стенах школьных кабинетов литературы, среди прочих изречений классиков, непременно была и цитата из Горького: «Всем хорошим во мне я обязан книгам».

Всем хорошим в моей профессиональной жизни я обязана Раисе Романовне Кузнецовой.

Конечно, ее научные заслуги несомненны, но об этом лучше расскажут другие ее ученики - те, кто посвятил жизнь науке. А мне хотелось бы рассказать, каким она была учителем.

Все началось с того, что меня выгнали из университета. К середине третьего курса было понятно, что заведующая славянской кафедрой Александра Григорьевна Широкова больше такую бездарную и ленивую студентку в своей чешской группе не потерпит: я училась из рук вон плохо, языки мне не давались, да и прилежания явно не хватало. Кроме того, если человека несколько лет называть свиньей, он и правда захрюкает, если двадцатилетней девушке заведующая кафедрой три года твердит, что она бездарь, девушка в это поверит.

Расставшись с университетом, я полтора года трудилась в районной библиотеке, а потом (повезло!) попала в «Литературную газету». Это был январь 1987 года, в отдел писем «Литературки» решили нанять временного сотрудника, чтобы разобрать завалы новогодней почты. А потом меня взяли уже на постоянную ставку.

Через полгода стало понятно - нужно доучиваться, и дорога мне на вечернее отделение родного филфака. Но оказалось, что на вечернее меня не возьмут, слишком велика разница в программах русского и славянского отделений: «Идите опять на свое славянское». Все доводы разбивались о заведующую вечерним отделением филфака как о скалу. И тут меня спасла Раиса Романовна. Она поручилась, что я сдам разницу (пятнадцать предметов) в течение года, а курсовые и диплом буду писать у нее.

Разницу я сдавала с удовольствием (это были в основном истории литератур: античка, зарубежка, русская - ведь на славянском читали только историю славянских литератур), а писать курсовые и диплом у Раисы Романовны - это вообще было счастье. В двадцать с небольшим какие только завиральные идеи в 
голову не приходят, какие только аналогии не выстраиваются. Помню реакцию нашей первой научной руководительницы (второй курс, первая моя курсовая работа): «чего?» на полях, и больше никаких комментариев. А Раиса Романовна терпеливо и подробно разбирала каждую мою литературоведческую «находку», и в конце концов подвела к очевидному: любая догадка (предположение, идея) по поводу литературного произведения только тогда имеет право на существование, если ее можно подтвердить авторским текстом. Разбирая недавно старые бумаги, я наткнулась на черновик своего диплома (сравнение очерков Марии Майеровой и рассказов Горького) - все поля исписаны комментариями моей научной руководительницы, а внизу - замечания почти на две страницы. И это не снисходительные поучающие замечания: она полемизировала со мной как с коллегой, на равных. И она ни разу не высмеяла мои тогдашние неуклюжие попытки скрестить Ленина с Бахтиным.

Потом, в аспирантуре, Раиса Романовна предложила мне писать диссертацию по Фране Шрамеку, и я благодарна, что она познакомила меня с этим писателем, сейчас незаслуженно забытым. Если говорить об импрессионизме в европейской литературе, без Шрамека не обойтись. Кстати, поскольку из трех его основных романов переведен на русский только один, мне пришлось подналечь на когдато ненавистный чешский. Говорить я не заговорила, но читала без труда - тоже спасибо за это моей научной руководительнице.

Четкого определения импрессионизма в литературе тогда не существовало, и мы вместе пытались его выработать, то есть Раиса Романовна «приводила меня в чувство», когда я начинала нести откровенный завиральный вздор. Но делала она это очень тактично, чтобы не отбить у меня охоту к «фантазированию». Не знаю, какую тактику Раиса Романовна выбирала с другими, наверняка к каждому у нее был индивидуальный подход. Но со мной она разговаривала так, что я ни разу не почувствовала себя смешной и глупой. Критиковать, не обижая, - дар настоящего учителя.

Тем временем в «Литературной газете» из отдела писем я перешла в отдел русской литературы. Начала публиковаться. И каждую мою публикацию, каждую мою рецензию Раиса Романовна внимательнейшим образом прочитывала и разбирала. И только благодаря ей мне (надеюсь) удалось избавиться от журналистского легкомыслия - желания ради красного словца слегка перетасовать факты. Именно она мне внушила, что в хорошей литературной журналистике действует то же правило, что и в научной работе: любое положение должно быть железно подкреплено текстом разбираемого произведения.

Первая половина девяностых - время коренной перестройки нашей литературы: «возвращение имен» уже состоялось, теперь хотелось «примерить на себя» модные западные направления. Возникали и исчезали новые газеты, журналы, издательства. Рождались и умирали «литературные авторитеты». И Раиса Романовна живо всем этим интересовалась, расспрашивала о новых авторах, о новых направлениях, ну и внутрилитературные «расклады сил» мы тоже, конечно, обсуждали. Вряд ли Раисе Романовне по душе было то, что происходило тогда в литературной жизни, но она стремилась понять, найти объяснение, выявить причины и предвидеть следствия, а не осуждать огульно.

Как-то мы приехали навестить Раису Романовну в Переделкино... Увидев меня, она тут же отметила: «Какая у вас красивая заколка!» - и тоже захотела такую - 
женщина всегда остается женщиной. А потом мы чуть не полдня говорили о постмодернизме.

В отношениях с ней невозможно было панибратство, дистанция всегда соблюдалась, - дистанция, обусловленная уважением ученика к учителю.

Профессор Московского университета - это ведь не формальное звание, это тот, кто создает научную среду, в которой только и возможно рождение открытия. Тесная связь между профессором и его учениками необходима не только для передачи «из рук в руки» знаний, но и для воспитания научной (и не только научной) этики. Это было традицией Московского университета - воздействие преподавателя на учеников личным примером, постоянное общение, обсуждение не только научной работы, но и всех текущих событий. Возможно, наше поколение (студенты восьмидесятых) застало «последних из Могикан». Но Раиса Романовна Кузнецова была именно такой - настоящим университетским профессором.

Сведения об авторе:

Татьяна Юрьевна Кравченко, литературный работник

сценарист

редактор

Член Союза российских писателей
Tatyana Kravchenko,

Literary Worker

Screenwriter

Editor

Member of the Union of Russian Writers 